\title{
EFFECT OF TEMPERATURE AND LIGHT ON SEED GERMINATION AND SEEDLING GROWTH OF Swietenia macrophylla King ${ }^{1}$
}

\author{
CLEVERSON AGUEIRO DE CARVALHO ${ }^{2}$, JOSUÉ BISPO DA SILVA ${ }^{3}$, CHARLINE ZARATIN ALVES $^{4} *$ CLIMBIÊ $^{3}$ \\ FERREIRA HALL ${ }^{3}$, MAYARA FÁVERO COTRIM ${ }^{5}$, ANIELE VERZOTTO TEIXEIRA ${ }^{4}$
}

\begin{abstract}
The significant economic potential of Swietenia macrophylla has caused immense reductions in the native populations, jeopardizing their survival. Restoring these populations requires the establishment of quality seedling production, which depends on adequate evaluation of the physiological state of seeds. Thus, the aim of this study was to evaluate the effect of temperature and light on seed germination and seedling growth of $S$. macrophylla. The experimental design was completely randomized, with ten treatments of four replicates of 50 seeds. Treatments consisted of: constant temperatures of $23,29,35$ and $41{ }^{\circ} \mathrm{C}$, with photoperiods of 24 and $12 \mathrm{~h}$ of light, and alternating temperatures of $25-35{ }^{\circ} \mathrm{C}$ and $30-40{ }^{\circ} \mathrm{C}$, with $12 \mathrm{~h}$ of light. Water content, germination, germination speed index, stem diameter, root length, shoot length, root dry mass and shoot dry mass of seedlings were evaluated. At $41{ }^{\circ} \mathrm{C}, S$. macrophylla seeds failed to germinate. A constant temperature of $29^{\circ} \mathrm{C}$ under $24 \mathrm{~h}$ of light favors the germination process of seeds and initial seedling growth.
\end{abstract}

Keywords: Mahogany. Forest seeds. Photoperiod.

\section{EFEITO DE TEMPERATURA E LUZ NA GERMINAÇÃO DE SEMENTES E CRESCIMENTO DE PLÂNTULAS DE Swietenia macrophylla King}

RESUMO - O significativo potencial econômico de Swietenia macrophylla tem causado redução intensa nas populações nativas, colocando em risco sua sobrevivência, exigindo assim, medidas para promover adequada avaliação do estado fisiológico das sementes, visando estabelecimento de um programa de qualidade de produção de mudas. Assim, o objetivo do presente estudo foi avaliar o efeito da temperatura e da luz sobre a germinação de sementes e o crescimento de plântulas de Swietenia macrophylla. O delineamento experimental foi o inteiramente casualizado, com dez tratamentos de quatro réplicas com 50 sementes, e constou de: temperaturas constantes de $23,29,35$ e $41{ }^{\circ} \mathrm{C}$, com fotoperíodo de 24 e $12 \mathrm{~h}$ de luz, e alternadas de $25-35^{\circ} \mathrm{C}$ e 30-40 ${ }^{\circ} \mathrm{C}$, com $12 \mathrm{~h}$ de luz. Avaliou-se o teor de água, germinação, índice de velocidade de germinação, diâmetro do coleto, comprimento de raiz e parte aérea, massa seca de raiz e parte aérea de plântulas. Germinação na temperatura de $41{ }^{\circ} \mathrm{C}$ é letal para sementes de $S$. macrophylla. O teste de germinação com temperatura constante de $29{ }^{\circ} \mathrm{C}$ sob $24 \mathrm{~h}$ de luz favorece o processo germinativo das sementes e o crescimento inicial das plântulas.

Palavras-chave: Mogno. Sementes florestais. Fotoperíodo.

\footnotetext{
${ }^{*}$ Corresponding author

${ }^{1}$ Received for publication in $12 / 06 / 2019$; accepted in 02/17/2020.

Paper extracted from the Cientific Initiation Program of the first author.

${ }^{2}$ Center for Biological and Natural Sciences, Universidade Federal do Acre, Rio Branco, AC, Brazil; cleversoncarvalho92@gmail.com ORCID: 0000-0002-3256-7023.

${ }^{3}$ Department of Biology, Universidade Federal de Mato Grosso do Sul, Três Lagoas, MS, Brazil; josue.bispo@ufms.br - ORCID: 00000002-0867-5913, climbiehall@gmail.com - ORCID: 0000-0002-6884-6091.

${ }^{4}$ Department of Agronomy, Universidade Federal de Mato Grosso do Sul, Chapadão do Sul, MS, Brazil; charline.alves@ufms.br - ORCID: 0000-0001-6228-078X, anielliverzottoteixeira@hotmail.com - ORCID: 0000-0003-3642-0923.

${ }^{5}$ Department of Phytotechnics, Food Technology and Economy, Universidade Estadual Paulista, Ilha Solteira, SP, Brazil; mayaracotrim5@gmail.com-ORCID: 0000-0003-0878-4922.
} 


\section{INTRODUCTION}

Brazil has numerous native tree species that are cultivated commercially on a large scale. Among them, mahogany (Swietenia macrophylla King. Meliaceae) is one with great productive potential (SOUZA et al., 2010). However, many plantations fail due to problems related to the cultivation conditions, such as seedling production (TUCCI; LIMA; LESSA, 2009), which is strongly influenced by seed quality. Therefore, it is indispensable to study the ecophysiological conditions influencing seed germination, since the success in the establishment of the species depends on the tolerance of the seedlings to the adverse conditions of the environment (SILVA et al., 2017).

Germination involves a series of metabolic activities, during which a programmed sequence of chemical reactions occurs, triggering demands on temperature. This occurs because germination depends on the activity of specific enzyme systems and on the physiological condition of the seed or on the insolubility of oxygen under these conditions, increasing its demands and accelerating the respiratory activity of the seeds (MARCOS FILHO, 2015).

Seeds usually have variable performance and there is no optimal and uniform temperature for germination (GUEDES et al., 2011). Thus, the methodology for germination testing used in the Instruções para Análise de Sementes de Espécies Florestais (BRAZIL, 2013) is based on studies that measured the influence of temperature, which can be constant (OLIVEIRA; DAVIDE; CARVALHO, 2008; PACHECO et al., 2010) or alternated (LIMA et al., 2011).

Species, region of origin, and natural occurrence may influence the effects of temperature on percentage of germination and speed of germination, because these factors directly influence water absorption by the seeds and the biochemical reactions that regulate the metabolism involved in this process (CARVALHO; NAKAGAWA, 2012).

Germination is also related to luminosity, since exposure to full sunlight causes variations in the initial chlorophyll fluorescence (DIAS; MARENCO, 2007), which is an important factor that influences the germination process. Generally, light and temperature have an interactive effect on photosensitive seed germination (MARCOS FILHO, 2015). This association is widely found in the literature for different species, such as Cedrela fissilis Vell. - Meliaceae (OLIVEIRA; BARBOSA, 2014), Dyckia goehringii E. Gross \& Rauh Bromeliaceae (DUARTE et al., 2010) and Chorisia glaziovii (Kuntze) E. Santos - Malvaceae (GUEDES; ALVES, 2011).

Swietenia macrophylla seed researches have addressed the effects of accelerated aging on normal seedling production, but evaluated the effect of treatments on the emergence of seedlings in sand (CARVALHO; SILVA; ALVES, 2016). Although the Instruções Para Análise de Sementes de Espécies Florestais (BRAZIL, 2013) explain the procedures for germination of this species, these studies did not evaluate the effects of temperature and light on the speed and timing of emergence and seedling growth. Such information is fundamental when searching for maximum efficiency in a seedling production system. The less time the seedlings take to emerge from the soil and remain in the early stages of development, the less vulnerable they are to adverse environmental conditions.

Therefore, studying the influence of temperature and light on germination and seedling growth is essential for the establishment of a reliable protocol to evaluate the germination potential of $S$. macrophylla seeds in the laboratory. Thus, the aim of this study was to evaluate the effects of temperature and light on seed germination and seedling growth of S. macrophylla.

\section{MATERIAL AND METHODS}

Swietenia macrophylla seeds were collected from five matrix trees in forest reserves near the municipalities of Rio Branco ( $9^{\circ} 58^{\prime} 29^{\prime \prime} \mathrm{S} ; 67^{\circ} 48^{\prime}$ $36^{\prime \prime} \mathrm{W}$; altitude $\left.153 \mathrm{~m}\right)$ and Sena Madureira ( $9^{\circ} 4^{\prime} 2^{\prime \prime}$ $\mathrm{S}$; $68^{\circ} 39^{\prime} 28^{\prime \prime} \mathrm{W}$; altitude $130 \mathrm{~m}$ ) of Acre State, Brazil. They were evaluated for: Water content determined by the standard method $\left(105 \square 3{ }^{\circ} \mathrm{C} / 24\right.$ h), according to the Instruções Para Análise de Sementes de Espécies Florestais (BRAZIL, 2013), using two replicates of 10 seeds each; Germination seeds were previously disinfected with sodium hypochlorite $(2.0 \%)$ for five minutes and then washed in running water. Four replicates of 25 seeds were placed in plastic boxes $(40 \times 30 \times 10 \mathrm{~cm})$ containing autoclaved sand $\left(120{ }^{\circ} \mathrm{C} / 1\right.$ atm for 20 $\min )$. Seeds were sown at $3 \mathrm{~cm}$ depth, and after the addition of $4 \mathrm{~mm}$ of water for substrate wetting, kept in a germination chamber. The equipment was maintained at constant temperatures of 23, 29, 35 and $41{ }^{\circ} \mathrm{C}$, with photoperiods of 12 and $24 \mathrm{~h}$, and alternating temperatures of $25-35^{\circ} \mathrm{C}$ and $30-40{ }^{\circ} \mathrm{C}$, with $12 \mathrm{~h}$ of light. Germination was evaluated daily from the $1^{\text {st }}$ to the $50^{\text {th }}$ day, and only seedlings with the hypocotyl elevated above the substrate were counted (BRAZIL, 2013); Germination speed index (GSI) - calculated by dividing the total number of germinated seeds (hypocotyl above the substrate), by the number of days elapsed since the test began (MAGUIRE, 1962); Mean germination time (MGT) - this variable was obtained by counting the number of seedlings that germinated after the test began, representing the mean time required for maximum emergence (LABORIAU, 1983); Relative 
germination frequency $(R G F)$ - frequency polygons were constructed by counting the number of seedlings that emerged per day until the final evaluation (LABOURIAU, 1983).

To evaluate the effects of temperature and light on the seedlings, at the end of the final germination test count, ten units were randomly selected and evaluated for stem diameter (at stemroot insertion); root length (between the mesocotyl and the terminal portion of the main root); and shoot length (between the mesocotyl and the point of insertion of the last pair of leaves), each determined by means of a digital caliper, with the results expressed in millimeters. The seedling roots and shoots were dried by being placed in Kraft paper containers in a greenhouse with forced air circulation at $70{ }^{\circ} \mathrm{C}$ for $72 \mathrm{~h}$, and their dry mass was determined with the aid of a precision scale (NAKAGAWA, 1999).

The experimental design was completely randomized, with four replicates of 25 seeds. Data were submitted to the assumptions of the analysis of variance, with verification of discrepant data by the Grubbs test, normality of the residues by the Shapiro Wilk test, and homogeneity of variances by the Bartlett test, through Assistat 7.7 Beta statistical software (SILVA, 2016). Results were submitted to analysis of variance and the means were compared by the Scott-Knott test $(\mathrm{p} \leq 0.05)$.

\section{RESULTS AND DISCUSSION}

The water content of seeds at the beginning of the tests was $8.8 \%$. There were differences for all temperature and light conditions. There was no germination at $41{ }^{\circ} \mathrm{C}$, under either 12 or $24 \mathrm{~h}$ of light, which demonstrates the thermal sensitivity of the seeds. Temperatures considered to be moderately high $\left(35\right.$ to $42{ }^{\circ} \mathrm{C}$ ) may cause direct damage to the photosynthetic apparatus, causing changes in the thylakoid membrane, altering the physicochemical properties and functional organization of these cellular structures (WISE et al., 2004). Parkia platycephala Benth. (Fabaceae) seeds present similar results when a temperature of $40{ }^{\circ} \mathrm{C}$ made evaluation of germination impossible (SILVA et al., 2017).

Treatments that provided superior germination were $23{ }^{\circ} \mathrm{C}$ with $24 \mathrm{~h}$ light, $29^{\circ} \mathrm{C}$ with $12 / 12$ light/dark, $29{ }^{\circ} \mathrm{C}$ with $24 \mathrm{~h}$ light, $35^{\circ} \mathrm{C}$ with $24 \mathrm{~h}$ light, and $25{ }^{\circ} \mathrm{C}$ with $12 \mathrm{~h}$ dark $/ 35^{\circ} \mathrm{C}$ with $12 \mathrm{~h}$ light (Table 1). These results show that the seeds had a high germination pattern, since the germination of this species varies from $42 \%$ to $98 \%$ (GOMES et al., 2007).

Table 1. Mean squares and germination (G \%), germination speed index (GSI), mean germination time (MGT - days), stem diameter (SD - mm), root length (RL - mm), shoot length $(\mathrm{SL}-\mathrm{mm})$, root dry weight (RDW - g) and shoot dry weight (SDW - g) of Swietenia macrophylla King. - Meliaceae) seedlings in different temperature and light conditions.

\begin{tabular}{|c|c|c|c|c|c|c|c|c|c|}
\hline \multirow{2}{*}{ Variation Source } & \multirow{2}{*}{$\begin{array}{l}\text { Degrees of } \\
\text { freedom }\end{array}$} & \multicolumn{8}{|c|}{ Mean squares } \\
\hline & & $\mathrm{G}$ & GSI & MGT & $\mathrm{SD}$ & $\mathrm{RL}$ & $\mathrm{SL}$ & RDW & SDW \\
\hline Treatments & 9 & $6100.62 * *$ & $0.62 * *$ & $156.02 * *$ & $3.99 * *$ & $39.45 * *$ & $154.09 * *$ & $12.46^{* *}$ & $8.67 * *$ \\
\hline Residuum & 30 & 16.80 & 0.002 & 2.59 & 0.003 & 0.17 & 0.37 & 0.04 & 0.007 \\
\hline \multicolumn{10}{|l|}{ Temperature/ Light } \\
\hline $23{ }^{\circ} \mathrm{C} / 24$ h light & & $93 a^{1}$ & $2.1 \mathrm{e}$ & $46 b$ & $2.6 \mathrm{~b}$ & $7.3 \mathrm{c}$ & $13.1 \mathrm{~d}$ & $3.8 \mathrm{c}$ & $3.4 \mathrm{~b}$ \\
\hline $29^{\circ} \mathrm{C} / 24 \mathrm{~h}$ light & & $96 a$ & $3.5 \mathrm{c}$ & $29 c$ & $2.8 \mathrm{a}$ & $7.3 \mathrm{c}$ & $15.2 b$ & $4.8 \mathrm{~b}$ & $4.1 \mathrm{a}$ \\
\hline $35^{\circ} \mathrm{C} / 24 \mathrm{~h}$ light & & $94 a$ & $4.3 \mathrm{a}$ & $22 \mathrm{e}$ & $2.1 \mathrm{e}$ & $7.0 \mathrm{c}$ & $11.0 \mathrm{e}$ & $3.5 \mathrm{~d}$ & $3.3 \mathrm{c}$ \\
\hline $23^{\circ} \mathrm{C} / 12 \mathrm{~h}$ light - & dark & $88 b$ & $1.8 \mathrm{e}$ & $49 a$ & $2.3 \mathrm{~d}$ & $7.7 \mathrm{~b}$ & $13.0 \mathrm{~d}$ & $5.1 \mathrm{a}$ & $3.3 \mathrm{c}$ \\
\hline $29{ }^{\circ} \mathrm{C} / 12 \mathrm{~h}$ light - & dark & $98 \mathrm{a}$ & $3.8 \mathrm{~b}$ & $27 d$ & $2.4 \mathrm{c}$ & $7.8 \mathrm{~b}$ & $15.8 \mathrm{~b}$ & $4.1 \mathrm{c}$ & $3.5 b$ \\
\hline $35^{\circ} \mathrm{C} / 12 \mathrm{~h}$ light - & dark & $80 c$ & $3.1 \mathrm{~d}$ & $31 \mathrm{c}$ & $2.1 \mathrm{e}$ & $8.7 \mathrm{a}$ & $11.4 \mathrm{e}$ & $3.4 \mathrm{~d}$ & $3.2 \mathrm{c}$ \\
\hline $25^{\circ} \mathrm{C} / 12 \mathrm{~h}$ dark - & $\mathrm{C} / 12 \mathrm{~h}$ light & $97 \mathrm{a}$ & $3.9 \mathrm{~b}$ & $25 \mathrm{~d}$ & $2.2 \mathrm{e}$ & $6.3 \mathrm{~d}$ & $17.8 \mathrm{a}$ & $3.3 \mathrm{~d}$ & $3.4 \mathrm{~b}$ \\
\hline $30{ }^{\circ} \mathrm{C} / 12 \mathrm{~h}$ dark - & $\mathrm{C} / 12 \mathrm{~h}$ light & $88 \mathrm{~b}$ & $3.5 \mathrm{c}$ & $26 \mathrm{~d}$ & $2.0 \mathrm{f}$ & $5.5 \mathrm{e}$ & $14.1 \mathrm{c}$ & $3.1 \mathrm{e}$ & $3.3 \mathrm{c}$ \\
\hline Coefficient of Var & $\mathrm{n}(\%)$ & 5.58 & 7.84 & 5.04 & 3.35 & 7.20 & 5.47 & 7.05 & 3.19 \\
\hline
\end{tabular}

${ }^{1}$ Means followed by the same letter, in the column, do not differ by the Scott Knott Test (5\%). **: significant values by the F test $(\mathrm{P} \leq 0.01)$.

Germination occurred at different temperatures, which demonstrates the adaptability of the species to natural thermal fluctuations of the environment, making them able to withstand adverse climatic conditions. Pereira et al. (2013) explain that a widely distributed species, such as $S$. macrophylla, which occurs naturally between latitudes $20^{\circ} \mathrm{N}$ in Mexico and $18^{\circ} \mathrm{S}$ in Bolivia, at altitudes up to 1500 $\mathrm{m}$, tends to be very flexible, with a wide range of conditions in which its seeds germinate and the seedlings survive. Thus, seeds collected in different regions may present different temperature requirements for germination, which is of paramount importance in the physiological evaluation of their ideal germination conditions.

In a study with a different Meliaceae species (Cedrela fissilis), using a $12 \mathrm{~h}$ photoperiod, germination was favored at both constant (20 and 25 $\left.{ }^{\circ} \mathrm{C}\right)$ and alternating $\left(20-30{ }^{\circ} \mathrm{C}\right)$ temperatures (OLIVEIRA; BARBOSA, 2014). Tabebuia aurea Benth. (Bignoniaceae) seeds also showed their highest germination performance at constant $(25,30$ 
and $\left.35^{\circ} \mathrm{C}\right)$ and alternated temperatures $(20-30$ and 20-35 ${ }^{\circ} \mathrm{C}$ ) (PACHECO et al., 2008).

The germination speed index was higher in the $35{ }^{\circ} \mathrm{C} / 24 \mathrm{~h}$ light treatment, which confirms that evaluating vigor by this test is more sensitive than percentage germination (MARCOS FILHO, 2015). Slower germination occurred at lower temperature $\left(23{ }^{\circ} \mathrm{C}\right)$, regardless of the duration of the light period. Thus, it is assumed that higher temperatures provided a more intense metabolic activity, in order to accelerate and standardize the germination process. This corroborates the findings of Carvalho and Nakagawa (2012), according to which, the higher the temperature, up to a certain limit, the faster and more uniform the germination.

Mean germination time ranged from 22 to 49 days between treatments, with higher values at $23{ }^{\circ} \mathrm{C}$ with $12 / 12 \mathrm{~h} \mathrm{light/dark}$, and lower values at $35^{\circ} \mathrm{C} / 24$ $\mathrm{h}$ light, a result also verified in the evaluation of GSI. In the study of Oliveira and Barbosa (2014), these two variables presented similar results, with extreme values at the higher and lower temperatures.

Stem diameter developed more at relatively mild temperatures and in total light presence $\left(29^{\circ} \mathrm{C}\right.$ with $24 \mathrm{~h}$ light), which corroborates the findings of Alves et al. (2016), in which seeds of Platymiscium floribundum Vogel. (Fabaceae) expressed maximum vigor in an illuminated environment. For Larcher (2000), diameter growth has a direct relationship with liquid photosynthesis, which depends on the accumulated carbohydrates and auxins, as well as the favorable balance between liquid photosynthesis and respiration.

The depth of the root system was greatest at constant temperature with light/dark alternation (35 ${ }^{\circ} \mathrm{C}$ with $12 / 12 \mathrm{~h} \mathrm{light/dark).} \mathrm{Contrarily,} \mathrm{Rosseto} \mathrm{et} \mathrm{al.}$ (2009) observed that the root length of Parkia pendula (Willd.) Benth. ex Walp. (Fabaceae) was higher at temperatures of 25 and $30{ }^{\circ} \mathrm{C}$ than at $35^{\circ} \mathrm{C}$.

The combination that allowed the highest development in shoot height was $25^{\circ} \mathrm{C}$ with $12 / 12 \mathrm{~h}$ dark/light. The time and photoperiod used to simulate the thermal and light fluctuations that occur in a natural environment in the $24 \mathrm{~h}$ interval may have positively influenced this variable. The lowest shoot growth occurred at a temperature/photoperiod of $35{ }^{\circ} \mathrm{C}$ with $12 / 12 \mathrm{~h}$ light/dark and $35{ }^{\circ} \mathrm{C} / 12 \mathrm{~h}$ light. In contrast, seedlings of $T$. aurea showed higher shoot growth at constant temperature of $35^{\circ}$ $\mathrm{C}$, but with only eight hours of light (PACHECO et al., 2008). In a study with seeds of Apeiba tibourbou Aubl. (Tiliaceae), a temperature of $35^{\circ} \mathrm{C}$ promoted greater length of the hypocotyl, when compared to other constant temperatures $\left(25\right.$ and $\left.30{ }^{\circ} \mathrm{C}\right)$ or alternated temperatures (20-30 and 20-35 $\left.{ }^{\circ} \mathrm{C}\right)$ (PACHECO et al., 2007).

The best conditions for the accumulation of dry matter were $23{ }^{\circ} \mathrm{C}$ with $12 / 12 \mathrm{~h}$ light/dark for the roots and $29{ }^{\circ} \mathrm{C}$ with $24 \mathrm{~h}$ light for the shoots. $A$. tibourbou had the highest values of dry matter of seedlings after seed treatments at temperatures between $25^{\circ} \mathrm{C}$ and $35^{\circ} \mathrm{C}$ (PACHECO et al., 2007).

Frequencies with several peaks (Figure 1), independent of temperature and light regime, indicate non-normal distribution to $S$. macrophylla seed germination, a characteristic that leads to unequipped germination (LABOURIAU, 1983), typical of species not genetically improved.

Relative germination frequency polygons (Figure 1) showed that in the $23{ }^{\circ} \mathrm{C} / 12 \mathrm{~h}$ light treatment there was a concentration of germination within a period of ten days, which only started 40 days after sowing, with a peak between 45 and 55 days. At $23{ }^{\circ} \mathrm{C} / 24 \mathrm{~h}$ light, the beginning of germination was delayed and germination had a greater time distribution. Germination at $29{ }^{\circ} \mathrm{C}$ preceded that at $23{ }^{\circ} \mathrm{C}$, starting at 19 days and lasting for 30 (24 h light) or 22 days (12 h light). This earlier onset was also observed in alternating temperatures of $25{ }^{\circ} \mathrm{C} / 12 \mathrm{~h}$ dark $-35{ }^{\circ} \mathrm{C} / 12 \mathrm{~h}$ light and $30{ }^{\circ} \mathrm{C} / 12 \mathrm{~h}$ dark $-40{ }^{\circ} \mathrm{C} / 12 \mathrm{~h}$ light and lasted for 25 days. At $35{ }^{\circ} \mathrm{C}$, germination began at 16 days, but lasted for 45 days with $12 \mathrm{~h}$ light and 20 days with $24 \mathrm{~h}$ light. The highest germination speed of the $35^{\circ}$ $\mathrm{C} / 24 \mathrm{~h}$ light combination also was also shown in the evaluations of germination speed index and mean germination time (Table 1).

The germination process was highly flexible under the conditions of the present study, showing superior performance in five of the eight temperature / light combinations. As for the discrepancy between the ideal conditions for the development of the plant verified in the literature and the present research, Mondo et al. (2010) explain that there are differences in temperature requirements for the development of different parts of the seedling. A difference of $1^{\circ} \mathrm{C}$ in temperature during the germination test is likely to have negligible effect on germination percentage, but it may have considerable effects on seedling growth by altering shoot length and / or dry matter (NAKAGAWA, 1999); the same reasoning can also be applied to the light requirement. 


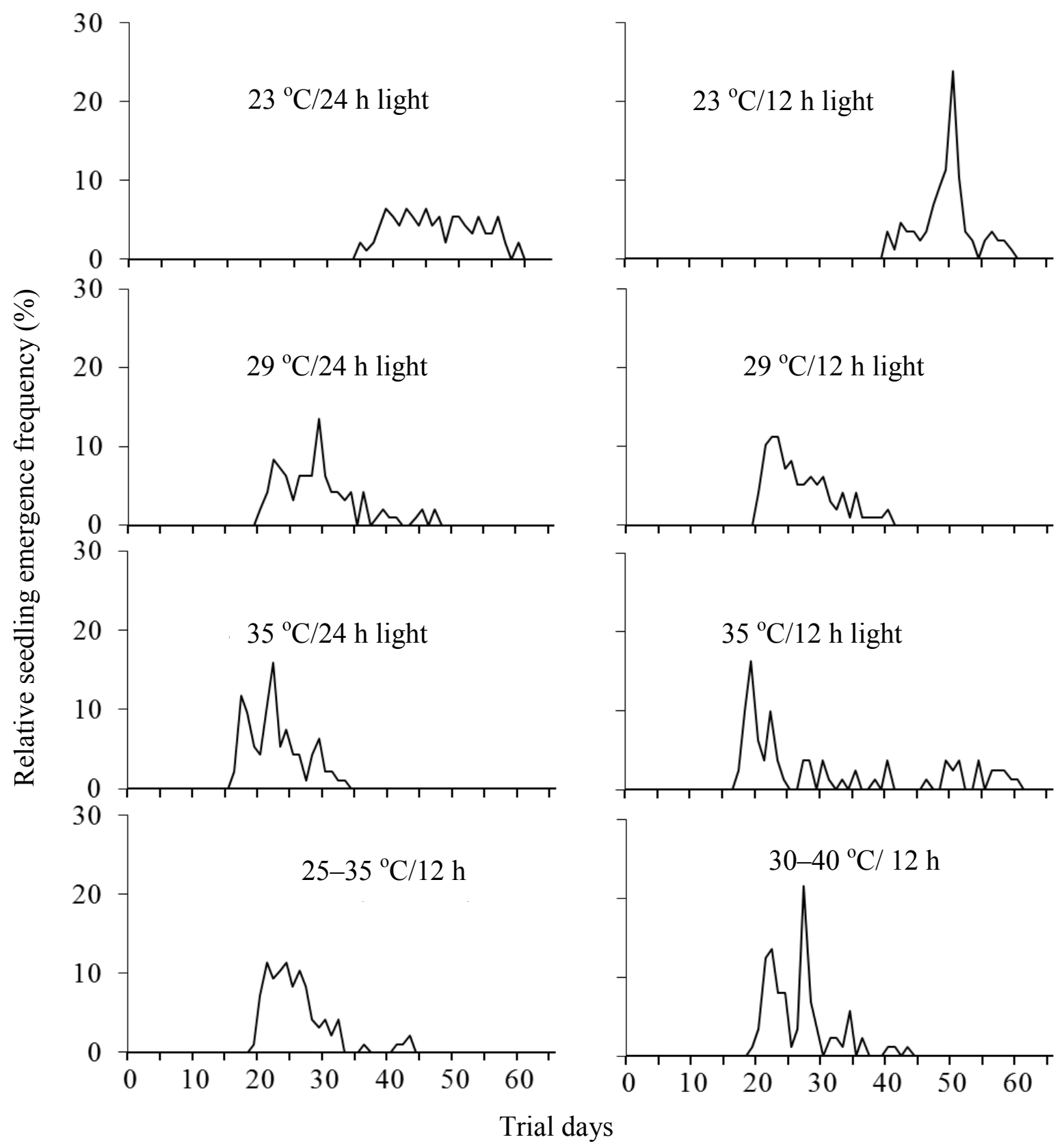

Figure 1. Relative frequencies of Swietenia macrophylla King. (Meliaceae) seed germination as a function of isothermal incubation time under different temperature and light conditions.

A temperature of $35{ }^{\circ} \mathrm{C}$ with $24 \mathrm{~h}$ light, provided a higher speed of germination, but did not present beneficial effects on the development of the seedlings. On the other hand, the combination of $29^{\circ}$ $\mathrm{C} / 24 \mathrm{~h}$ light delayed germination by three days (compared to $35^{\circ} \mathrm{C} / 24 \mathrm{~h}$ light), but was one of the combinations that provided the maximum germination, development of the stem diameter, dry matter accumulation in the shoot, and concentration of germination.

\section{CONCLUSION}

A temperature of $41{ }^{\circ} \mathrm{C}$ in the germination test prevents germination of S. macrophylla seeds. On the other hand, a constant temperature of $29{ }^{\circ} \mathrm{C}$ under $24 \mathrm{~h}$ of light favors seed germination and the initial growth of seedlings.

\section{ACKNOWLEDGMENT}

This study was financed in part by Universidade Federal de Mato Grosso do Sul and the Coordenação de Aperfeiçoamento de Pessoal de Nível Superior - Brasil (CAPES) - Finance Code 001.

The authors thank PhD Bryon Richard Hall for the language review. 


\section{REFERENCES}

ALVES, M. M. et al. Germinação de sementes de Platymiscium floribundum vog. (Fabaceae) sob a influência da luz e temperaturas. Ciência Florestal, 26: 971-978, 2016.

BRAZIL. Ministério da Agricultura, Pecuária e Abastecimento. Secretaria de Defesa Agropecuária. Instruções para análise de sementes de espécies florestais. Brasília: MAPA/CGAL, 2013. 97 p.

CARVAlHO, C. A., SIlvA. J. B.; AlVES, C. Z. Envelhecimento acelerado em sementes de mogno. Revista Ciência Agronômica, 47: 691-699, 2016.

CARVAlHO, N. M.; NAKAGAWA, J. Sementes: ciência, tecnologia e produção. 5. ed. Jaboticabal, SP: FUNEP, 2012. 590 p.

DIAS, P. D.; MARENCO, R. A. Fotossíntese e fotoinibição em mogno e acariquara em função da luminosidade e temperatura foliar. Pesquisa Agropecuária Brasileira, 42: 305-311, 2007.

DUARTE, E. F. et al. Características físicas e germinação de sementes de Dyckia goehringii Gross $\&$ Rauh (Bromeliaceae) sob diferentes temperaturas. Pesquisa Agropecuária Tropical, 40: 422-429, 2010.

GUEDES, R. S.; ALVES, E. U. Substratos e temperaturas para o teste de germinação de sementes de Chorisia glaziovii (O. Kuntze). Cerne, 17: 525$531,2011$.

GUEDES, R. S. et al. Germinação de sementes de Dalbergia nigra (Vell.) Fr. All. Acta Scientiarum, 33: 445-450, 2011.

GOMES, J. I. et al. Conhecendo espécies de plantas da Amazônia: Mogno (Swietenia macrophylla King - Meliaceae). 1. ed .Belém, PA: Embrapa Amazônia Oriental, 2015. 7 p. (Comunicado técnico, 266).

LABOURIAU, L. G. A germinação das sementes. Washington: Secretaria da OEA, 1983. 173 p.

LARCHER, W. Ecofisiologia vegetal. 1. ed. São Carlos, SP: Rima, 2000. 531 p.

LIMA, C. R. et al. Temperaturas e substratos na germinação de sementes de Caesalpinia pyramidalis Tul. Journal of Seed Science, 33: 216-222, 2011.

MAGUIRE, J. D. Speed of germination-aid in selection and evaluation for seedling emergence and vigor. Crop Science, 2: 176-177, 1962.
MARCOS FILHO, J. Fisiologia de sementes de plantas cultivadas. 2. Ed. Londrina, PR: ABRATES, 2015. 660 p.

MONDO, V. H. V. et al. Efeito da luz e temperatura na germinação de sementes de quatro espécies de plantas daninhas do gênero Digitaria. Journal of Seed Science, 32: 131-137, 2010.

NAKAGAWA, J. Testes de vigor baseados no desempenho das plântulas. In: KRZYZANOWSKI, F. C.; VIEIRA, R. D.; FRANÇA NETO, J. B. (Eds.). Vigor de sementes: conceitos e testes. Londrina: ABRATES, 1999. cap. 2, p. 1-24.

OLIVEIRA, A. K. M.; BARBOSA, L. A. Efeitos da temperatura na germinação de sementes e na formação de plântulas de Cedrela fissilis. Floresta, 44: 441 - 450, 2014.

OLIVEIRA, L. M.; DAVIDE, A. C.; CARVALHO, M. L. M. Teste de germinação de sementes de Peltophorum dubium (Sprengel) Taubert - Fabaceae. Floresta, 38: 545-551, 2008.

PACHECO, M. V. et al. Germinação de sementes de Apeiba tibourbou Aubl. em função de diferentes substratos e temperaturas. Scientia Forestalis, 73: 19-25, 2007.

PACHECO, M. V. et al. Germinação de sementes e crescimento inicial de plântulas de Tabebuia áurea (Silva Manso) Benth. \& Hook f. ex S. Moore. Ciência Florestal, 18: 143-150, 2008.

PACHECO, M. V. et al. Germination and vigor of Dimorphandra mollis Benth. seeds under different temperatures and substrates. Revista Árvore, 34: 205-213, 2010

PEREIRA, S. R. et al. Influência da temperatura na germinação de sementes de Peltophorum dubium (Spreng.) Taub. Informativo ABRATES, 23: 52-55, 2013.

ROSSETO, J. et al. Germinação de sementes de Parkia pendula (Willd.) Benth. ex Walp. (Fabaceae) em diferentes temperaturas. Revista Árvore, 33: 4755, 2009.

\section{SILVA, F. A. S. Sistema de Assistência Estatística} - ASSISTAT Versão 7.7 beta. 2016.

SILVA, R. B. et al. Germinação e vigor de plântulas de Parkia platycephala Benth., em diferentes substratos e temperaturas. Revista Ciência Agronômica, 48: 142-150, 2017.

SOUZA, E. B. et al. Exigências nutricionais e crescimento de plantas de mogno (Swietenia 
macrophylla King.). Acta Amazônica, 40: 515-522, 2010.

TUCCI, C. A. F.; LIMA, H. N.; LESSA, J. F. Adubação nitrogenada na produção de mudas de mogno (Swietenia macrophylla King). Acta Amazônica, 39: 289-294, 2009.

WISE, R. R. et al. Electron transport is the functional limitation of photosynthesis in field-grown Pima cotton plants at high temperature. Plant, Cell and Environment, 27: 717-724, 2004. 